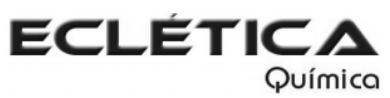

www.scielo.br/eq

www.ecletica.iq.unesp.br

Volume 33, número 2, 2008

\title{
Self-assembly of supermolecular species directed by hydrogen bonding and aromatic $\pi-\pi$ stacking interactions
}

\author{
X.H. Li1, A. F. Jalbout $t^{2 *}$ and W.D. Xiang ${ }^{1}$ \\ ${ }^{\prime}$ College of Chemistry and Materials Engineering, Wenzhou University, Wenzhou, Zhejiang 325027, P.R.China \\ ${ }^{2}$ Instituto de Quimica, Universidad Nacional Autonoma de Mexico, Mexico D.F. \\ *ajalbout@u.arizona.edu
}

\begin{abstract}
A new $\mathrm{Cu}(\mathrm{II})$ trimers, $\left[\mathrm{Cu}_{3}(\mathrm{dcp})_{2}\left(\mathrm{H}_{2} \mathrm{O}\right)_{8}\right]$. 4DMF, with the ligand 3,5-pyrazoledicarboxylic acid monohydrate $\left(\mathrm{H}_{3} \mathrm{dcp}\right)$ has been prepared by solvent method. Its solid-state structure has been characterized by elemental analysis, thermal analysis (TGA and DSC), and single crystal X-ray diffraction. X-ray crystallographic studies reveal that this complex has extended 1-D,2-D and 3-D supramolecular architectures directed by weak interactions (hydrogen bond and aromatic $\pi-\pi$ stacking interaction) leading to a sandwich solid-state structure.
\end{abstract}

Keywords: Copper complex; crystal structure; supramolecular; $\pi-\pi$ interaction.

\section{Introduction}

Recently, the design and synthesis of supramolecules that provide new shapes, sizes and chemical environments as well as the searches for new functional materials causes an incessant interest in supramolecular chemistry [1-10]. This is not only due to their complicated structural diversity, but also they are fundamental steps to discover and fabricate various fundamental supramolecular devices or technologically useful materials [11-15]. In the synthesis of supramolecular inorganic architectures by design, the assembly of molecular units in predefined arrangements is a key goal[16-18]. Directional intermolecular interactions are the primary tools in achieving this goal and hydrogen bonding is currently the best among them[19-20]. The use of noncovalent interactions (such as the hydrogen bonds and aromatic $\pi-\pi$ stacking interactions) to arrange molecular building blocks has evolved into one of the most useful and flexible strategies for the crystal engineering design of extended constitutes that have versatile functions [21-25].

$\mathrm{H}_{3} \mathrm{dcp}$ (Scheme 1) is a suitable candidate for assembling supramolecular structure due to its two interesting structural features. At first, it has multiple coordination sites that allow structures of higher dimensions involving both the nitrogen atoms of the pyrazole ring and all of the carboxylate oxygens. These multifunctional coordination sites are highly accessible to metal ions; $\mathrm{H}_{3}$ pdc can coordinate as a mono-, bi-, or tetradentate ligand and can act to link together to the metal centers through a number of bridging modes. A variety of its coordination compounds containing transition, lanthanide and alkalineearth metals have been synthesized and reported in the literature [26-30]. Second, it can act both as an excellent hydrogen donor and hydrogen acceptor in hydrogen bonding, which interactions are fundamental in supramolecular chemistry. Furthermore, there are strong $\pi-\pi$ stacking interactions between pyrazole rings, which can consolidate the framework. All 
the factors above strongly stimulate our interest, in this paper, we report a new $\mathrm{Cu}$ (II) trimers, $\left[\mathrm{Cu}_{3}(\mathrm{dcp})_{2}\left(\mathrm{H}_{2} \mathrm{O}\right)_{8}\right] \cdot 4 \mathrm{DMF}$. Interestingly, the complex exhibits a sandwich structure, which is constructed by intense intermolecular hydrogen bond and aromatic $\pi-\pi$ interaction.

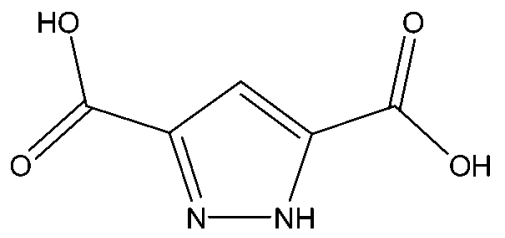

$$
\mathrm{H}_{3} \mathrm{dcp}
$$

Scheme 1.

\section{Experimental}

\section{Materials and instrumentation}

All reagents were commercially obtained and used without any further purification. Elemental analyses $(\mathrm{C}, \mathrm{H}$ and $\mathrm{N})$ were carried out on a Carlo-Erba 1112 Elemental Analyzer. Crystal structure was obtained on a Bruker Smart-1000 CCD diffractometer. Thermogravimetric (TGA) and calorimetric analyses were performed on a SDT Q600 V5.0 Build 63 simul- taneous thermobalance and a differential scanning calorimeter (DSC), respectively, at $20^{\circ} \mathrm{C}$ $\mathrm{min}^{-1}$ to a maximum temperature of $825^{\circ} \mathrm{C}$ in dynamic dinitrogen atmosphere of approximately $150 \mathrm{~cm}^{3} \mathrm{~min}^{-1}$.

\section{Synthesis of the title compound}

Copper(II) sulfate pentahydrate $(0.25 \mathrm{~g}, 1$ mmol) was dissovled in water $(10 \mathrm{~mL})$, then, a DMF solution $(10 \mathrm{~mL})$ of 2,2 '-bipyridine $(0.16 \mathrm{~g}$, $1 \mathrm{mmol})$, and 3,5-pyrazoledicarboxylic acid (0.16 g, $1 \mathrm{mmol})$ was added dropwise with stirring at $298 \mathrm{~K}$ temperature. Then the reaction mixture was filtered and the filtrate stood for about two weeks until the blue single crystals were obtained. The prism shaped crystals suitable for X-ray diffraction were collected by filtration, washed with water and ethanol and dried in air. Yield 40\%. Anal. Calcd for $\mathrm{C}_{22} \mathrm{H}_{46} \mathrm{~N}_{8} \mathrm{O}_{20}$ $\mathrm{Cu}_{3}(\%) \mathrm{C}, 28.29$; H, 4.93; N, 12.00. Found: C, 28.36; H, 5.02; N, 11.88 .

\section{$X$-ray crystallography}

All measurements were made on a Bruker Smart-1000 CCD diffractometer with graphite monochromated Mo-K $\alpha$ radiation $(\lambda=0.071073$ $\mathrm{nm})$ using $\omega$-scan technique. Determination of the Laue class, orientation matrix, and cell dimensions were performed according to the established procedures. Lorentz polarization and absorption corrections were applied. Absorption

Table 1. Crystallographic data and structure refinement summary for the title complex 1 .

\begin{tabular}{llll}
\hline Formula & $\mathrm{C}_{22} \mathrm{H}_{46} \mathrm{~N}_{8} \mathrm{O}_{20} \mathrm{Cu}_{3}$ & Crystal size $\left(\mathrm{mm}^{3}\right)$ & $0.37 \times 0.28 \times 0.10$ \\
Formula weight & 933.29 & $\theta$ range $\left(^{\circ}\right)$ & 0.92 to 25.01 \\
Temperature $(\mathrm{K})$ & $298(2)$ & Limiting indices & $-27 \leq \mathrm{h} \leq 25,-10 \leq \mathrm{k} \leq 9,-23 \leq \mathrm{l} \leq 23$ \\
Wavelength $(\AA)$ & 0.71073 & Reflections collected/unique & $19297 / 6702[\mathrm{R}(\mathrm{int})=0.0555]$ \\
Crystal system & Monoclinic & Completeness to theta $=25.1$ & $99.8 \%$ \\
space group & $\mathrm{P} 2{ }_{1} / \mathrm{c}$ & $\mathrm{F}(000)$ & 1924 \\
$\mathrm{a}(\mathrm{nm})$ & $2.27572(6)$ & Absorption correction & Semi-empirical from equivalents \\
$\mathrm{b}(\mathrm{nm})$ & $0.86509(3)$ & Max. and min. transmission & 0.8450 and 0.5649 \\
$\mathrm{c}(\mathrm{nm})$ & $1.99830(9)$ & Refinement method & Full-matrix least-squares on $\mathrm{F}^{2}$ \\
$\beta\left({ }^{\circ}\right)$ & $104.038(2)$ & Data / restraints/parameters & $6702 / 0 / 499$ \\
Volume $\left(\mathrm{nm}^{3}\right)$ & $3.8166(2)$ & Goodness-of-fit on $\mathrm{F}^{2}$ & 1.103 \\
$\mathrm{Z}$ & 4 & Final R indices [I $>2$ sigma $(\mathrm{I})]$ & $\mathrm{R}_{1}=0.0661, \mathrm{wR}_{2}=0.1358$ \\
Dc $\left(\mathrm{g} / \mathrm{cm}^{3}\right)$ & $1.624 \times 10^{3}$ & R indices (all data) & $\mathrm{R}_{1}=0.0926, \mathrm{wR}_{2}=0.1463$ \\
Absorption $\left(\mathrm{mm}^{-1}\right)$ & 1.743 & Largest diff. peak and hole $\left(\AA^{-3}\right)$ & 1.077 and -0.729 \\
\hline
\end{tabular}


corrections were applied by fitting a pseudoellipsoid to the $\omega$-scan data of selected strong reflections over a wide range of $2 \theta$ angles. Most of the non-hydrogen atoms in the crystal structure were located with the direct methods, and subsequent Fourier syntheses were used to derive the remaining non-hydrogen atoms. All of non-hydrogen atoms were refined anisotropically, and all of the hydrogen atoms were held stationary and included in the final stage of fullmatrix least-squares refinement based on $F 2$ using the SHELXS-97 and SHELXL-97 programs package[31-32]. The crystal data are given in Table 1. The select bond lengths and bond angles are given in Table 2. The hydrogen bonding data is given in table 3 .

\section{Results and discussion}

\section{Crystal structures}

Determination of the structure by X-ray crystallography reveals that the complex consists of zero-dimensional lattices of $\left[\mathrm{Cu}_{3}(\mathrm{pdc})_{2}\left(\mathrm{H}_{2} \mathrm{O}\right)_{8}\right]$. 4DMF trimers. The trinuclear unit is nearly co-planar which contains a six-coordinate and two five-coordinate $\mathrm{Cu}(\mathrm{II})$ ions bridged by two dcp ${ }^{3-}$ trianions. The basic trinuclear unit does not link to the adjacent trimers, which results in the formation of the crystallographic 0-D lattices. Four DMF molecules link to the unit through hydrogen bonds. Compared to $\left[\mathrm{Cu}_{3}(\mathrm{dcp})_{2}\left(\mathrm{H}_{2} \mathrm{O}\right)_{4}\right]$, in which a copper atom lies on a crystallographic inversion

Table 2. Selected bond lengths $(\AA)$ and bond angles $\left(^{\circ}\right)$ for the title complex 1 at $298 \mathrm{~K}$.

\begin{tabular}{|c|c|c|c|}
\hline \multicolumn{4}{|c|}{ Bond lengths $(\AA)$} \\
\hline $\mathrm{Cu}(1)-\mathrm{O}(11)$ & $1.943(4)$ & $\mathrm{Cu}(1)-\mathrm{O}(2)$ & $1.960(4)$ \\
\hline $\mathrm{Cu}(1)-\mathrm{O}(9)$ & $2.003(4)$ & $\mathrm{Cu}(1)-\mathrm{N}(1)$ & $2.030(4)$ \\
\hline $\mathrm{Cu}(1)-\mathrm{O}(10)$ & $2.345(4)$ & $\mathrm{Cu}(2)-\mathrm{O}(4)$ & $1.961(4)$ \\
\hline $\mathrm{Cu}(2)-\mathrm{O}(5)$ & $1.962(4)$ & $\mathrm{Cu}(2)-\mathrm{N}(2)$ & $1.983(4)$ \\
\hline $\mathrm{Cu}(2)-\mathrm{N}(3)$ & $1.996(4)$ & $\mathrm{Cu}(2)-\mathrm{O}(12)$ & $2.247(4)$ \\
\hline $\mathrm{Cu}(3)-\mathrm{O}(14)$ & $1.930(3)$ & $\mathrm{Cu}(3)-\mathrm{O}(7)$ & $1.943(4)$ \\
\hline $\mathrm{Cu}(3)-\mathrm{O}(13)$ & $1.975(4)$ & $\mathrm{Cu}(3)-\mathrm{N}(4)$ & $1.986(4)$ \\
\hline $\mathrm{Cu}(3)-\mathrm{O}(15)$ & $2.321(4)$ & & \\
\hline \multicolumn{4}{|c|}{ Bond angles $\left({ }^{\circ}\right)$} \\
\hline $\mathrm{O}(11)-\mathrm{Cu}(1)-\mathrm{O}(2)$ & $174.57(15)$ & $\mathrm{O}(11)-\mathrm{Cu}(1)-\mathrm{O}(9)$ & $90.90(15)$ \\
\hline $\mathrm{O}(2)-\mathrm{Cu}(1)-\mathrm{O}(9)$ & $84.07(15)$ & $\mathrm{O}(11)-\mathrm{Cu}(1)-\mathrm{N}(1)$ & $103.40(16)$ \\
\hline $\mathrm{O}(2)-\mathrm{Cu}(1)-\mathrm{N}(1)$ & $81.66(15)$ & $\mathrm{O}(9)-\mathrm{Cu}(1)-\mathrm{N}(1)$ & $165.69(16)$ \\
\hline $\mathrm{O}(11)-\mathrm{Cu}(1)-\mathrm{O}(10)$ & $89.70(15)$ & $\mathrm{O}(2)-\mathrm{Cu}(1)-\mathrm{O}(10)$ & $92.06(16)$ \\
\hline $\mathrm{O}(9)-\mathrm{Cu}(1)-\mathrm{O}(10)$ & $86.72(15)$ & $\mathrm{N}(1)-\mathrm{Cu}(1)-\mathrm{O}(10)$ & $92.62(16)$ \\
\hline $\mathrm{O}(4)-\mathrm{Cu}(2)-\mathrm{O}(5)$ & $169.62(17)$ & $\mathrm{O}(4)-\mathrm{Cu}(2)-\mathrm{N}(2)$ & $82.45(16)$ \\
\hline $\mathrm{O}(5)-\mathrm{Cu}(2)-\mathrm{N}(2)$ & $96.02(16)$ & $\mathrm{O}(4)-\mathrm{Cu}(2)-\mathrm{N}(3)$ & $97.31(16)$ \\
\hline $\mathrm{O}(5)-\mathrm{Cu}(2)-\mathrm{N}(3)$ & $82.10(16)$ & $\mathrm{N}(2)-\mathrm{Cu}(2)-\mathrm{N}(3)$ & $168.33(17)$ \\
\hline $\mathrm{O}(4)-\mathrm{Cu}(2)-\mathrm{O}(12)$ & $94.07(16)$ & $\mathrm{O}(5)-\mathrm{Cu}(2)-\mathrm{O}(12)$ & $96.32(17)$ \\
\hline $\mathrm{N}(2)-\mathrm{Cu}(2)-\mathrm{O}(12)$ & $97.67(17)$ & $\mathrm{N}(3)-\mathrm{Cu}(2)-\mathrm{O}(12)$ & $93.99(16)$ \\
\hline $\mathrm{O}(14)-\mathrm{Cu}(3)-\mathrm{O}(7)$ & $173.16(16)$ & $\mathrm{O}(14)-\mathrm{Cu}(3)-\mathrm{O}(13)$ & $87.71(16)$ \\
\hline $\mathrm{O}(7)-\mathrm{Cu}(3)-\mathrm{O}(13)$ & $86.28(16)$ & $\mathrm{O}(14)-\mathrm{Cu}(3)-\mathrm{N}(4)$ & $101.49(16)$ \\
\hline $\mathrm{O}(7)-\mathrm{Cu}(3)-\mathrm{N}(4)$ & $83.19(16)$ & $\mathrm{O}(13)-\mathrm{Cu}(3)-\mathrm{N}(4)$ & $159.46(18)$ \\
\hline $\mathrm{O}(14)-\mathrm{Cu}(3)-\mathrm{O}(15)$ & $93.51(14)$ & $\mathrm{O}(7)-\mathrm{Cu}(3)-\mathrm{O}(15)$ & $90.81(15)$ \\
\hline
\end{tabular}

${ }^{a}$ Symmetry transformations used to generate equivalent atoms: $\mathrm{B}-\mathrm{x}+1 / 2$, $\mathrm{y}+1 / 2,-\mathrm{z}+1 / 2 ; \mathrm{C} \mathrm{x}, \mathrm{y}+1, \mathrm{z}$. 
Table 3. Hydrogen bonds for $\left[\mathrm{Cu}_{3}(\mathrm{pdc})_{2}\left(\mathrm{H}_{2} \mathrm{O}\right)_{8}\right]$. 4DMF $\left(\AA\right.$ and $\left.^{\circ}\right)$.

\begin{tabular}{lcccc}
\hline $\mathrm{D}-\mathrm{H} \ldots \mathrm{A}$ & $\mathrm{d}(\mathrm{D}-\mathrm{H})$ & $\mathrm{d}(\mathrm{H} \ldots \mathrm{A})$ & $\mathrm{d}(\mathrm{D} \ldots \mathrm{A})$ & $<(\mathrm{DHA})$ \\
$\mathrm{O}(20)-\mathrm{H}(20 \mathrm{D}) \ldots \mathrm{O}(3) \# 1$ & $0.73(10)$ & $2.08(10)$ & $2.809(6)$ & $169(11)$ \\
$\mathrm{O}(20)-\mathrm{H}(20 \mathrm{E}) \ldots \mathrm{O}(17) \# 2$ & $0.72(10)$ & $2.05(10)$ & $2.719(5)$ & $156(11)$ \\
$\mathrm{O}(15)-\mathrm{H}(15) \ldots \mathrm{O}(6) \# 3$ & 0.82 & 2.13 & $2.874(4)$ & 149.4 \\
$\mathrm{O}(15)-\mathrm{H}(15 \mathrm{D}) \ldots \mathrm{O}(19) \# 4$ & 0.82 & 1.90 & $2.714(8)$ & 172.1 \\
$\mathrm{O}(14)-\mathrm{H}(14) \ldots \mathrm{O}(4)$ & 0.82 & 1.79 & $2.604(3)$ & 171.9 \\
$\mathrm{O}(14)-\mathrm{H}(14 \mathrm{D}) \ldots \mathrm{O}(2) \# 2$ & 0.82 & 1.95 & $2.746(3)$ & 165.1 \\
$\mathrm{O}(13)-\mathrm{H}(13) \ldots \mathrm{O}(2) \# 2$ & 0.82 & 2.61 & $3.267(4)$ & 138.3 \\
$\mathrm{O}(13)-\mathrm{H}(13) \ldots \mathrm{O}(1) \# 2$ & 0.82 & 1.94 & $2.691(4)$ & 150.7 \\
$\mathrm{O}(13)-\mathrm{H}(13 \mathrm{D}) \ldots \mathrm{O}(20) \# 3$ & 0.82 & 1.92 & $2.736(4)$ & 174.1 \\
$\mathrm{O}(12)-\mathrm{H}(12) \ldots \mathrm{O}(18) \# 5$ & 0.83 & 1.88 & $2.690(9)$ & 166.2 \\
$\mathrm{O}(12)-\mathrm{H}(12 \mathrm{D}) \ldots \mathrm{O}(1) \# 6$ & 0.82 & 1.93 & $2.748(4)$ & 171.6 \\
$\mathrm{O}(11)-\mathrm{H}(11) \ldots \mathrm{O}(7) \# 7$ & 0.82 & 1.93 & $2.750(4)$ & 173.3 \\
$\mathrm{O}(11)-\mathrm{H}(11 \mathrm{D}) \ldots \mathrm{O}(5)$ & 0.82 & 1.81 & $2.623(3)$ & 171.9 \\
$\mathrm{O}(10)-\mathrm{H}(10) \ldots \mathrm{O}(16) \# 2$ & 0.83 & 1.97 & $2.756(7)$ & 158.4 \\
$\mathrm{O}(10)-\mathrm{H}(10 \mathrm{~A}) \ldots \mathrm{O}(6) \# 8$ & 0.82 & 2.01 & $2.808(4)$ & 165.8 \\
$\mathrm{O}(9)-\mathrm{H}(9) \ldots \mathrm{O}(15) \# 1$ & 0.82 & 2.46 & $2.853(4)$ & 110.5 \\
$\mathrm{O}(9)-\mathrm{H}(9 \mathrm{~A}) \ldots \mathrm{O}(7) \# 7$ & 0.82 & 2.54 & $3.272(5)$ & 148.8 \\
$\mathrm{O}(9)-\mathrm{H}(9 \mathrm{~A}) \ldots \mathrm{O}(8) \# 7$ & 0.82 & 1.97 & $2.728(5)$ & 153.6 \\
\hline $\mathrm{S}$ & & & &
\end{tabular}

Symmetry transformations used to generate equivalent atoms: \#1=x,$\mathrm{y}+3 / 2, \mathrm{z}+1 / 2, \# 2=\mathrm{x},-\mathrm{y}+3 / 2, \mathrm{z}-1 / 2, \# 3=\mathrm{x},-\mathrm{y}+1 / 2, \mathrm{z}-1 / 2$, \#4 x+1,-y+1/2,z-1/2, \#5= $-\mathrm{x}+1, \mathrm{y}-1 / 2,-\mathrm{z}+1 / 2, \# 6=\mathrm{x}, \mathrm{y}-1, \mathrm{z}, \# 7=\mathrm{x},-\mathrm{y}+1 / 2, \mathrm{z}+1 / 2, \# 8=\mathrm{x}, \mathrm{y}+1, \mathrm{z}$

center [33], this complex doesn't have an inversion center. Here, dcp ${ }^{3-}$ coordinates as a tetradentate ligand.

As shown in figure $1, \mathrm{Cu}(1)$ atom is sixcoordinated and has a distorted octahedron geometry. A pyrazole nitrogen $\mathrm{N}(1)$ and a carboxylate oxygen $\mathrm{O}(2)$ from one carboxylate group of a pdc 3- trianion occupy two coordination sites on $\mathrm{Cu}$ (1). Four further positions are occupied by oxygens from four $\mathrm{H}_{2} \mathrm{O}$ molecules. The angles subtended the $\mathrm{Cu}(1)$ range from $89.70(15) .^{\circ}$ to $92.62(16) .^{\circ}$ The distortion from octahedral geometry of the $\mathrm{Cu}(1)$ site is a result of ligand constraints and the Jahn-Teller effect. the latter is responsible for the elongated axial bonds.

In the case of the central pentacoordinate copper in the trimeric unit, the geometry of $\mathrm{Cu}(2)$ atom is a transmutative square-pyramidal which is defined by $\mathrm{Cu}(2), \mathrm{O}(4), \mathrm{O}(5), \mathrm{N}(2), \mathrm{N}(3)$ and $\mathrm{O}(12)$. Two pyrazole nitrogen atoms $[\mathrm{Cu}(2)-$ $\mathrm{N}(3), 1.996(4) \AA ; \mathrm{Cu}(2)-\mathrm{N}(2) 1.983(4) \AA]$, and Two carboxylate oxygen atoms $[\mathrm{Cu}(2)-\mathrm{O}(5)$, 1.962(4) $\AA$; $\mathrm{Cu}(2)-\mathrm{O}(4)$ 1.961(4) $\AA$ ], from pdc ${ }^{3-}$ ligands form the distorted equatorial plane

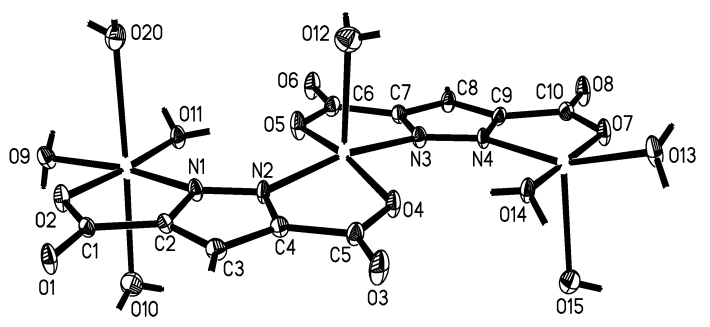

Figure 1. ORTEP drawing with labeling scheme for $\left[\mathrm{Cu}_{3}(\mathrm{pdc})_{2}\left(\mathrm{H}_{2} \mathrm{O}\right)_{8}\right]$. 4DMF (1), DMF molecules are omitted for clarity.

around $\mathrm{Cu}(2)$ with a chelating angle $\mathrm{O}(5)-\mathrm{Cu}(2)-$ $\mathrm{N}(3)$ of only $82.10(16)^{\circ} \mathrm{C}$. The remaining axial coordination sites are occupied by an oxygen from a $\mathrm{H}_{2} \mathrm{O}$ molecule $[\mathrm{Cu}(2)-\mathrm{O}(12), 2.247(4) \AA]$.

The $\mathrm{Cu}(3)$ atom has a pentacoordinate geometry which is intermediate between squarepyramidal and trigonal-bipyramidal. A pde ${ }^{3-}$ ligand chelate to $\mathrm{Cu}(3)$ through a carbaxylate oxygen and adjacent nitrogen atoms $(\mathrm{O}(7) / \mathrm{N}(4))$, occupying two coordination sites of $\mathrm{Cu}(3)$, the others are taken by three $\mathrm{H}_{2} \mathrm{O}$ molecules $(\mathrm{O}(3), \mathrm{O}(14), \mathrm{O}(15))$. 
As shown in Figure 2, strong intermolecular hydrogen bond exists between the trimers, resulting in an one-dimensional supramolecular ribbon, which is strengthened by $\pi-\pi$ stacking interaction. Further hydrogen-bonding among the ribbons leads to a two-dimensional $\mathrm{H}$-bonded sheet (Fig.3). A sandwich structure has been formed in the whole three-dimensional stacking (see Fig.4). The DMF guest in the title compound

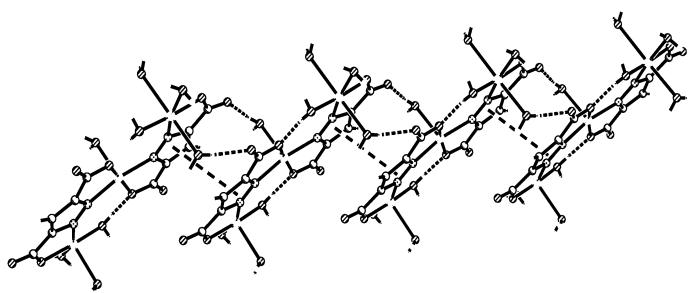

Figure 2. Stereoview of the 1-D linear structure of 1 constructed by hydrogen bonds and $\pi-\pi$ stacking interactions.

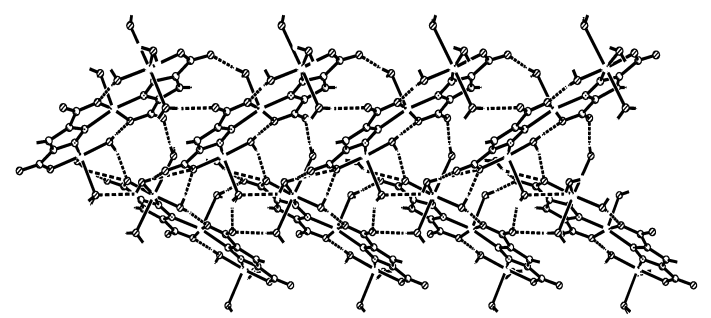

Figure 3. Stereoview of the 2-D sheet structure of 1 constructed by hydrogen bonds.

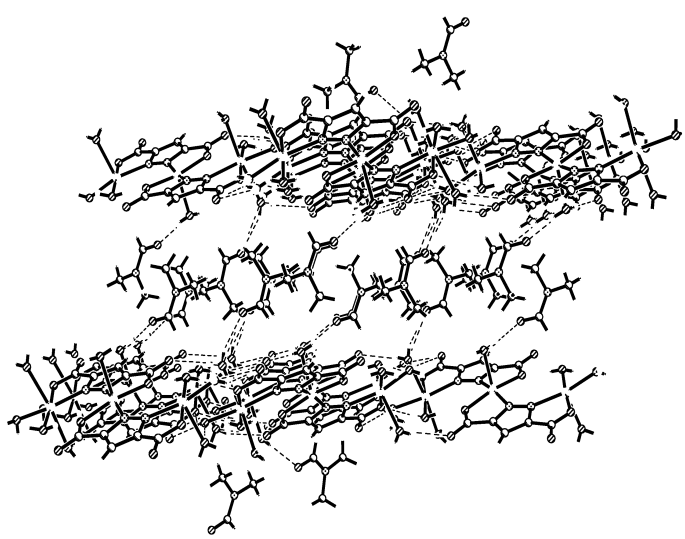

Figure 4. Stereoview of the 3-D sandwich structure of 1 constructed by hydrogen bonds. disposed between the mutually parallel planes of two planes of Fig. 3 and is coordinated to each of them by intermolecular hydrogen bonds and other interactions.

The structure of the complex is shown in an undulated one-dimension ribbon constructed by hydrogen bonds and $\pi . . . \pi$ stacking interactions, Fig. 2. Undoubtedly, the hydrogen bonding plays important roles in the stabilization of the title complex. Two neighboring $\mathrm{HMA}^{+}$cations are held together by $\mathrm{N}-\mathrm{H}$... N hydrogen bond, meanwhile, there are strong $\pi$... $\pi$ stacking interactions between two $\mathrm{HMA}^{+}$cations from adjacent layers to yield molecular ribbon. $\mathrm{HMA}^{+}$cations in adjacent unit cell related by an inverse centre are connected by pairs to form undulate ribbons via $\mathrm{R}_{2}{ }_{2}(8)$ ring motifs, each composed of two pairs of $\mathrm{N}-\mathrm{H} \ldots \mathrm{N}$ hydrogen bonds [ $\mathrm{N}(7) \ldots \mathrm{N}(10)$ \#6 2.994(6) , $\mathrm{N}(2) \ldots \mathrm{N}(6) \# 7$ 3.048(7) ̊̊]. The $\mathrm{R}_{2}^{2}$ (8) hydrogenbonded motifs involving $\mathrm{N}-\mathrm{H}$... $\mathrm{N}$ hydrogen bonds has been found in the crystal structures of many MA complexes [27,29, 37-39].

As we can see from Fig. 3, the ribbons are held together in a three-dimensional microporous arrangement by the intense intermolecular (N-H...O and O-H...O) hydrogen bonds. Between the protonated aromatic/amino nitrogen atoms of MA and the sulfate oxygenatoms, the ribbons of $\mathrm{HMA}^{+}$cations and $\mathrm{SO}_{4}{ }^{2-}$ anions are interconnected alternatively, giving rise to a 14-membered hydrogen bonded $\mathrm{R}_{3}{ }_{3}(14)$ ring motifs[ $\mathrm{N}(3) \ldots \mathrm{N}(11)$

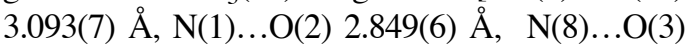
$2.989(6) \AA]$ to generate corrugated layers. Interestingly, the $\mathrm{O}(2)$ and $\mathrm{O}(3)$ atoms of $\mathrm{SO}_{4}{ }^{2-}$ bridge two amino hydrogen atoms from two different $\mathrm{HMA}^{+}$cations respectively, while $\mathrm{O}(1)$ and $\mathrm{O}(4)$ atoms connect two triazine nitrogen atoms from two different $\mathrm{HMA}^{+}$cations and two oxygen atoms from two water molecules $[\mathrm{O}(1)$...O(6) 2.815(7) $\AA$, O (2) $\# 1$...O(6) 2.904(7) $\AA$ ]. The adjacent ribbons are also hydrogen-bonded through water molecules to the amino groups $[\mathrm{N}(2) \ldots \mathrm{O}(6) \quad \# 8 \quad 3.025(7) \AA$, N3...O(6) \#4 2.941(7) Å]. Such ribbons extend into a layer structure. These layers are stacking into a 3$\mathrm{D}$ microporous network (Fig. 3) by (N-H...O, $\mathrm{N}-\mathrm{H} . . . \mathrm{N}, \mathrm{O}-\mathrm{H} . . . \mathrm{O})$ hydrogen bonds. Meanwhile, there are strong $\pi . . . \pi$ stacking interactions between the $\mathrm{HMA}^{+}$cations from adjacent layers, which are found to consolidate the undulated ribbons. 


\section{Thermal analysis}

DMF molecules linked to the trimmer by weak hydrogen bonds. This action is weaker than the coordination action of water molecules and pdc $^{3-}$ trianions obviously. Compare to tetradentate pdc $^{3-} 1$ trianions, water molecules only coordinate copper(II) ion by one oxygen atom. So, the decomposed order is DMF, water and pdc ${ }^{3-}$ ligand.

The thermal behavior of the title coordination compound has been deduced from the TG analysis in nitrogen atmosphere. A crystalline sample was heated at a constant rate of $10^{\circ} \mathrm{C} / \mathrm{min}$ from 40 to $800^{\circ} \mathrm{C}$. The sample lost weight immediately. Just as what we have been supposed: the weight loss at $50-200{ }^{\circ} \mathrm{C}$ is considered as the loss of four DMF guests in each formula unit 31.0\% (calcd 31.3\%). And the sheet (see Fig.2) is left. The weight loss at $200-250^{\circ} \mathrm{C}$ is considered as the loss of eight ligand water molecules, $15.0 \%$ (calcd 15.4\%). This means the complex has been disassembled. At $250-650^{\circ} \mathrm{C}$, there is a obviously exothermic progress. It is ascribed to decomposition of the organic acid ligands.

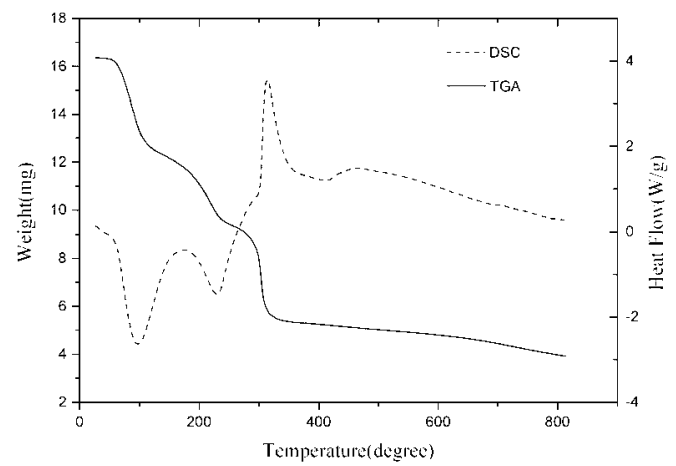

Figure 5. TGA $=\%$ mass loss, $\mathrm{DSC}=\Delta \mathrm{T}(\mu \mathrm{V})$ curves at $20^{\circ} \mathrm{C} \mathrm{m^{-1 }}$ in dynamic dinitrogen atmosphere at $150 \mathrm{~cm}^{3} \mathrm{~min}^{-1}\left[\mathrm{Cu}_{3}(\mathrm{pdc})_{2}\left(\mathrm{H}_{2} \mathrm{O}\right)_{8}\right]$. 4DMF.

The thermal decomposition behavior of the title supramolecular complex has been followed up to $800{ }^{\circ} \mathrm{C}$ by the thermogravimetric (TGA) and differential scanning calorimeter (DSC) analysis. The TGA curve shows that the complex is stable up to $500{ }^{\circ} \mathrm{C}$, above which its structure begins to collapse. The TGA and DSC curves exhibit a continuous weigh loss, indicating a multi-step decomposition of the complex.

The TGA curve shows that the weight loss of $9.54 \%$ in the temperature range $50-310{ }^{\circ} \mathrm{C}$ can be attributed to the removal of two water molecules (Cacld 9.3\%). The violently exothermic peak between $310-400{ }^{\circ} \mathrm{C}$ is attributed to the degradation of the sulfate dianion with the weight loss of $24.24 \%$ which is in good agreement with the result obtained from X-ray diffraction $(24.85 \%$ for one sulfate dianion). The weight loss of $35.11 \%$ in the temperature range $400-500{ }^{\circ} \mathrm{C}$ is in agreement with the weight loss calculated for the loss of melamine molecules (Calcd 32.64\%). The weight drops off sharply between 500 and $610{ }^{\circ} \mathrm{C}$ attributed to framework decomposition. The decomposition process of the complex ends at around $650{ }^{\circ} \mathrm{C}$.

The DSC curve display three endothermic peaks at 135,355 and $490{ }^{\circ} \mathrm{C}$ due to the elimination of water molecule, sulfate dianion, MA, respectively, and a exothermic peak at $610{ }^{\circ} \mathrm{C}$ which is ascribed to decomposition of melamine cations. The TGA and DSC curves reveal the intensity of interactions in the complex (Water molecules < sulfate dianion $<\mathrm{MA}$ ). According to the DSC curve, Water molecules and sulfate dianion link to MA only with hydrogen bonds. When the complex is heated, water molecule is vaporized first, then is sulfate dianion. This phenomena indicates that the hydrogen bonding interaction of water molecules is much weaker than sulfate dianion. The MA cation disconnect last at $500{ }^{\circ} \mathrm{C}$ due to the intense hydrogen bonding and aromatic $\pi-\pi$ stacking interaction between MA cations.

\section{Conclusions}

A trimer complex of $\left[\mathrm{Cu}_{3}(\mathrm{pdc})_{2}\left(\mathrm{H}_{2} \mathrm{O}\right)_{8}\right]$. $4 \mathrm{DMF}$ is prepared by solution method. Its structure is a zero-dimensional lattice. The weak interactions (hydrogen bonding and aromatic $\pi-\pi$ stacking interaction) between each unit result in a sandwich supramolecule .

A new MA-sulfate cocrystal is obtained, which exhibits interesting hydrogen bonding patterns and 3-D microporous structure. This kind of hydrogen bonding patterns and 3-D microporous structure is rarely seen in other similar MA com- 
plexes. There are three kinds of hydrogen bonds (N-H...O, N-H...N, O-H...O) which sustain the microporous structure. The hydrogen-bonding patterns include the commonly observed $\mathrm{R}_{2}{ }_{2}(8)$ ring motifs and the less commonly observed $\mathrm{R}_{3}^{3}(14)$ ring motifs. The results demonstrate that the main driving forces in the formation of the final 3D structures are intermolecular hydrogen bonding and $\pi-\pi$ stacking interactions. The thermal analysis supports the results of this supramolecular structure and reveals the intensity of interactions in the complex.

\section{Acknowledgement}

We acknowledge financial support by the $\mathrm{S} \& \mathrm{~T}$ project of Zhejiang Province (No. 2007C31035), the $S \&$ T project of Wenzhou (No. G20060097 and G20060090), and the Nation Natural Science Foundation of China (grant No. 50772075 and 50472018).

\section{Supporting Information Available}

CCDC-628830 contains the supplementary crystallographic data for this paper. These data can be obtained free of charge at www.ccdc.cam.ac.uk/conts/ retrieving.html [or from the Cambridge Crystallographic Data Center, 12, Union Road, Cambridge CB2 1EZ, UK; fax: (internat.) +44-1223/336-033; E-mail: deposit@ccdc.cam.ac.uk].

Received 26 February 2008

Accepted 28 April 2008

\section{References}

[1] T.K. Maji, K. Uemura, H.-C. Chang, R. Matsuda, S. Kitagawa, Angew. Chem. Int. Ed. 43 (2004) 3269.

[2] F.A. Cotton, C. Lin, C.A. Murillo, Acc. Chem. Res. 34 (2001) 759.
[3] A. Morsali, A.R. Mahjoub, Polyhedron 23 (2004) 2427.

[4] S. Kawata, S. Kitagawa, H. Kumagai, C. Kudo, H. Kamesaki, T. Ishiyama, R. Suzuki, M. Kondo, M. Katada, Inorg. Chem. 35 (1996) 4445.

[5] O.M. Yaghi, C.E. Davis, G. Li, H. Li, J. Am. Chem. Soc. 119 (1997) 2861.

[6] D. Dobrzyjska, T. Lis, L.B. Jerzykiewicz, Inorg. Chem. Commun. 8 (2005) 1090.

[7] J.P. GarcÌa-Ter•n, O. Castillo, A. Laque, U. GarciaCouceivo, P. Rom·n, F. Lloret, Inorg. Chem. 43 (2004) 5761. [8] A.M. Chippindale, M.R. Grimshaw, A.V. Powell, A.R. Cowley, Inorg. Chem. 44 (2005) 4121.

[9] S.J. Loeb, Chem. Commun. (2005) 1511.

[10] T.K. Maji, G. Mostafa, H.-C. Chang, S. Kitagawa, Chem. Commun. (2005) 2439.

[11] O.M. Yaghi, H. Li, J. Am. Chem. Soc. 118 (1996) 295.

[12] Q. Wei, M. Nieuwenhuyzen, F. Meunier, C. Hardacre, S.L. James, J. Chem. Soc. Dalton Trans. (2004) 1807.

[13] A.R. Millward, O.M. Yaghi, J. Am. Chem. Soc. 127 (2005) 17998.

[14] B.J. Holliday, C.A. Mirkin, Angew. Chem. Int. Ed. 40 (2001) 2022.

[15] P.J. Hagraman, D. Hagrman, J. Zubieta, Angew. Chem. Int. Ed. 38 (1999) 2638.

[16] G. R. Desiraju, Angew Chem. Int. Ed. Engl. 34 (1995) 2311.

[17] G. R. Desiraju, Chem. Commun. (1997)1475.

[18] D. Braga, F. Grepioni, G. R. Desiraju, Chem. Rev. 98 (1998) 1375.

[19] D. Braga, F. Grepioni, Acc. Chem. Res. 33 (2000) 601.

[20] M. J. Zaworotko, Nature (London), 386 (1997) 220.

[21] S.-I. Noro, H. Miyasaka, S. Kitagawa, T. Wada, T. Okubo, M. Yamashita, T. Mitani, Inorg. Chem. 44 (2005) 133. [22] P. Diaz, J. Benet-Buchholz, R. Vilar, A.J.P. White, Inorg. Chem. 45 (2006) 1617.

[23] F.S. Delgado, J. Sanchiz, C. Ruiz-PÈrez, F. Lloret, M. Julve, Inorg. Chem. 42 (2003) 5938.

[24] H.W. Roesky, M. Andruh, Coord. Chem. Rev. 236 (2003) 91. [25] E. Colacio, F. Lloret, R. Kivekäs, J. Ruiz, J. SuärezVarela, M.R. Sunberg, Chem. Commun. (2002) 592.

[26] Pan. L, Ching. N, Huang. X, Li. J. Chem. Eur. J. 7 (2001) 4431- 4437.

[27] Wenkin. M, Devillers. M, Tinant. B, Declercq. J. Inorg. Chim. Acta 258 (1997) 113-118.

[28] Sanna. D, Micera. G, Buglyo. P, Kiss. T, Gajda. T, Surdy.P. Inorg. Chim. Acta 268 (1998) 297-305.

[29] Sakagami. N, Nakahanada. M, Ino. K, Hioki. A, Kaizaki. S. Inorg. Chem. 35 (1996) 683-688.

[30] Nakahanada. M, Ino. K, Kaizaki. S. J. Chem. Soc., Dalton Trans. (1993) 3681-3684.

[31] G. M. Sheldrick, SHELXTL Version 5, Siemens, Industrial Automation Inc., Madison, Wisconsin, U. S. A., 1995.

[32] G.M. Sheldrick, SHELXK97, Programs for Crystal Structure Analysis, University of Go“ttingen, Germany, 1997. [33] Philippa King, Rodolphe Cle'rac, Christopher E. Anson, Claude Coulon, and Annie K. Powell, Inorg. Chem. 42 (2003) 3492-3500. 